\title{
Side-effects of supplementation of vitamin $D$ in a patient with sarcoidosis - a case study
}

\author{
Efekty uboczne suplementacji witaminy D u pacjentki z sarkoidozą - opis \\ przypadku
}

\author{
Agata Betlejewska ${ }^{1, A-F \oplus}$ \\ ${ }^{1}$ Department of Nephrology, Medical University, Lublin, Poland \\ A - Research concept and design, B - Collection and/or assembly of data, C - Data analysis and interpretation, \\ $D$ - Writing the article, $E$ - Critical revision of the article, $F$ - Final approval of article
}

Betlejewska A. Side-effects of supplementation of vitamin D in a patient with sarcoidosis - a case study. Med Og Nauk Zdr. 2020; 26(4): 403-405. doi: 10.26444/monz/131222

\begin{abstract}
Introduction. Vitamin D supplementation is an important clinical issue due to frequent deficiencies of this prohormone. In rare cases, however, its oversupply can lead to side-effects, such as hypercalcaemia. The following is a clinical case of a patient with diagnosed sarcoidosis who suffered from acute kidney injury in the course of hypercalcaemia due to an oversupply of vitamin 25(OH)D. The patient, after several measurements of vitamin 25(OH)D in the blood where its deficit was determined, started its supplementation. After several weeks, she began to suffer from different somatic afflictions: fatigue, headache, persistent constipation. In laboratory tests, acute kidney injury was determined. The patient was referred to the Nephrology Department where conservative treatment was introduced. During hospitalization, other causes of acute kidney injury and hyperkalcaemia were excluded. During the course of treatment, improvement in the patient's condition was achieved. Also the parameters of serum creatinine and calcium level slowly decreased. Treatment for vitamin $D$ deficiency is an extremely important issue in everyday medical work. However, it is important to consider possible side-effects of the drugs used, as well as specific recommendations for certain groups of patients. These include, among others, patients with granulomatous diseases, such as tuberculosis or sarcoidosis.
\end{abstract}

Conclusion. Not all groups of patients should be given supplementation of vitamin $D$, but in patients receiving the supplementation calcium serum levels should be monitored.

\section{Key words}

sarcoidosis, vitamin D, acute kidney injury, hypercalcemia

\section{Streszczenie}

Suplementacja witaminy $\mathrm{D}$ jest ważnym zagadnieniem klinicznym z uwagi na występujące często niedobory tego prohormonu. W rzadkich przypadkach nadmierna jej podaż może jednak doprowadzić do efektów ubocznych, do których należy m.in. hiperkalcemia. Poniżej przedstawiono przypadek kliniczny chorej z rozpoznaną sarkoidozą, u której doszło do ostrego uszkodzenia nerek w przebiegu hiperkalcemii w wyniku nadmiernej podaży witaminy 25(OH)D. Po kilkukrotnych oznaczeniach witaminy 25(OH) D i stwierdzonych niedoborach do leczenia chorej włączono suplementację tej witaminy. Po kilku tygodniach leczenia kobieta zaczęła uskarżać się na liczne dolegliwości somatyczne, takie jak osłabienie, bóle głowy, uporczywe zaparcia. W efekcie wykonanych badań stwierdzono cechy ostrego uszkodzenia nerek. Pacjentka została skierowana do kliniki nefrologii, gdzie rozpoczęto leczenie zachowawcze. W trakcie hospitalizacji przeprowadzono diagnostykę różnicową ostrego uszkodzenia nerek oraz hiperkalcemii, wykluczając inne przyczyny stanu chorej. Zastosowanym leczeniem zachowawczym uzyskano stopniową poprawę stanu pacjentki oraz ustąpienie dolegliwości somatycznych. Parametry funkcji nerek oraz stężenia wapnia obniżyły się. Leczenie niedoborów witaminy $D$ jest niezwykle ważnym zagadnieniem w codziennej pracy lekarskiej. Należy jednak pamiętać o możliwych skutkach ubocznych stosowanych leków, jak również o specyficznych zaleceniach dla niektórych grup chorych. Należą do nich m.in. pacjenci z chorobami ziarniniakowymi, takimi jak gruźlica czy sarkoidoza. Podsumowując, nie wszyscy chorzy, u których występują niedobry witaminy D, powinni otrzymywać jej suplementację. Ponadto u pacjentów stosujących suplementację witaminy $D$ należy okresowo monitorować stężenie wapnia w surowicy krwi.

\section{Słowa kluczowe}

sarkoidoza, witamina D, ostre uszkodzenie nerek, hiperkalcemia

\section{INTRODUCTION}

Address for correspondence: Agata Betlejewska, Klinika Nefrologii, Uniwersytet Medyczny w Lublinie, Jaczewskiego 8, 20-954, Lublin, Polska

E-mail: agata_betlejewska@wp.pl

Received: 16.09.2020; accepted: 07.12.2020; first published: 18.12.2020

Vitamin D is a steroid prohormone from which the active hormone calcitriol is formed as a result of a number of metabolic changes. Until recently, the main focus was on the effect of vitamin D on the regulation of calcium-phosphate 
metabolism and its role in the development of diseases such as osteoporosis, osteomalacia and rickets in children. In recent years, however, vitamin D deficiency has been proven to play a role in the development of many other diseases, such as cancer, autoimmune diseases, cardiovascular diseases, and even depression or neurodegenerative diseases [1]. In Central and Eastern Europe, deficits of this prohormone are frequent; therefore, especially in the autumn-winter period in our latitude, its supplementation is recommended. According to the Guidelines for Supplementation of Vitamin $\mathrm{D}$ for Central Europe, the supplementation at the dose of 800-2,000 IU/day from September - April should be applied in persons $>18$ years of age, and in persons $>65$ years of age this dose should be taken all year round. However, in the case of shortages or deficiencies, the therapeutic doses may be as high as 7,000-10,000 IU/day [2].

\section{CASE REPORT}

A 50-year-old female patient who had been under the control of the Pulmonology Outpatient Clinic for sarcoidosis for 3 years, was referred to the Department of Nephrology with rapidly progressing renal failure of unknown etiology. In control tests performed 3 months before admission to the Clinic, normal kidney function was observed, determined creatinine level - $0.9 \mathrm{mg} / \mathrm{dl}$, EGFR $>90 \mathrm{ml} / \mathrm{min} / 1.73 \mathrm{~m}^{\wedge} 2$ of body surface. Creatinine level determined just before admission - $2.14 \mathrm{mg} / \mathrm{dl}$, EGFR $26.3 \mathrm{ml} / \mathrm{min} / 1.73 \mathrm{~m}^{\wedge} 2$. The initial diagnosis of acute kidney injury was made, and the patient admitted to the Ward in an emergency procedure. On admission, the patient was in a good general condition. She reported headaches, increased sleepiness and fatigue, persistent constipation, nausea and vomiting after meals, which also occurred during the first 2 days of hospitalization. She did not observe increased diuresis, but the daily urine collection showed moderate polyuria of 3-4 liters. Additionally, her medical history showed arterial hypertension and lipid metabolism disorders. In the past, the patient had been suffering from depressive disorders. Currently, the patient was treated with torasemide and telmisartan, which was introduced 5 days before hospitalization in the Clinic. For about 3 months she also took vitamin D supplementation in the amount of 50 drops/week (1 drop = $500 \mathrm{IU})$, recommended because of its deficiency. The determined level of vitamin $\mathrm{D}$ at the onset of supplementation amounted to $18.73 \mathrm{ng} / \mathrm{ml}(\mathrm{N} 30-50 \mathrm{ng} / \mathrm{ml})$. She was therefore taking about 3,500 IU per day, which was in the recommended supplemental doses in the case of vitamin D deficiency in a healthy population. The patient also reported that due to frequent headaches she was taking large amounts of nonsteroid anti-inflammatory drugs. In laboratory tests carried out in the Department of Nephrology, attention was drawn to a significant degree of hypercalcaemia - $14.1 \mathrm{mg} / \mathrm{dl}(\mathrm{N}$ 8.7-10.4 mg/dl) (Tab.1). The remaining laboratory parameters determined on admission are presented in Table 1. Physical examination did not show any signs of patient dehydration or other significant deviations from the norm.

The patient was instructed to discontinue the vitamin $\mathrm{D}$ supplementation. Fluid therapy in the amount of 2 litres of saline and diuretic treatment - $60 \mathrm{mg}$ of furosemide intravenously in divided doses was introduced. Due to a moderate decrease in calcium levels, hydrocortison in
Table 1. Results of laboratory tests performed on admission

\begin{tabular}{|c|c|c|}
\hline Parameter & Result & The standard range \\
\hline WBC & $8.36 \times 10^{\wedge} 12 / L$ & $4.0-10.0 \times 10^{\wedge} 12 / L$ \\
\hline HBG & $12.1 \mathrm{~g} / \mathrm{dL}$ & $12.0-16.0 \mathrm{~g} / \mathrm{dL}$ \\
\hline $\mathrm{HCT}$ & $35.7 \%$ & $37.0-47.0 \%$ \\
\hline PLT & $222 \times 10^{\wedge} 9 / \mathrm{L}$ & $150-400 \times 10^{\wedge} 9 / \mathrm{L}$ \\
\hline Glucose & 98 mg/dl & $70-99$ mg/dl \\
\hline Potassium & $4.8 \mathrm{mmol} / \mathrm{L}$ & $3.5-5.1 \mathrm{mmol} / \mathrm{L}$ \\
\hline $\mathrm{Na}$ & $139 \mathrm{mmol} / \mathrm{L}$ & $136-145 \mathrm{mmol} / \mathrm{L}$ \\
\hline ALT & $12 \mathrm{U} / \mathrm{L}$ & $<34 \mathrm{U} / \mathrm{L}$ \\
\hline AST & $17 \mathrm{U} / \mathrm{L}$ & $<31 \mathrm{U} / \mathrm{L}$ \\
\hline CRP & $8.891 \mathrm{mg} / \mathrm{l}$ & $0.0-5.0 \mathrm{mg} / \mathrm{l}$ \\
\hline Urea & $56.4 \mathrm{mg} / \mathrm{dl}$ & $19.26-49.22 \mathrm{mg} / \mathrm{dl}$ \\
\hline Uric acids & $6.7 \mathrm{mg} / \mathrm{dl}$ & $<5.7 \mathrm{mg} / \mathrm{dl}$ \\
\hline Creatinine & $1.8 \mathrm{mg} / \mathrm{dl}$ & $0.5-1.1 \mathrm{mg} / \mathrm{dl}$ \\
\hline EGFR & $32.5 \mathrm{ml} / \mathrm{min} / 1.73 \mathrm{~m}^{\wedge} 2$ & $>90 \mathrm{ml} / \mathrm{min} / 1.73 \mathrm{~m}^{\wedge} 2$ \\
\hline Calciun & $14.1 \mathrm{mg} / \mathrm{dl}$ & $8.7-10.4 \mathrm{mg} / \mathrm{dl}$ \\
\hline Phosphorus & $4.3 \mathrm{mg} / \mathrm{dl}$ & $2.4-5.1 \mathrm{mg} / \mathrm{dl}$ \\
\hline $\mathrm{pH}$ & 7.33 & $7.32-7.45$ \\
\hline $\mathrm{HCO} 3$ & $30.2 \mathrm{mmol} / \mathrm{l}$ & $24-28 \mathrm{mmol} / \mathrm{l}$ \\
\hline TSH & $1.258 \mathrm{mIU} / \mathrm{L}$ & $0.55-4.78 \mathrm{mlU} / \mathrm{L}$ \\
\hline
\end{tabular}

WBC - white blood cell; HBG - haemoglobine; HCT - haematocrit; PLT - platelets; Na- sodium; ALT - alanine transaminaze; AST - aspartate transaminaze. CRP - C-reactive protein.

a dose of $2 \times 50 \mathrm{mg}$ was also added to the treatment after 2 days. At the same time, diagnostics were performed for other causes of hypercalcaemia. The determined levels of total protein, immunoglobulins IgG, IgM and IgA were normal. Monoclonal total protein by immunofixation was absent. Tumur markers CEA, AFP, Ca19-9, Ca125 and Ca15-3 were negative. Parathormone level - 14 pg/ml (N 18.4-80, 1 pg/ml). The patient had a chest X-ray performed, an ultrasound of the abdominal cavity, and a gynaecological ultrasound. She was consulted gynaecologically and pulmonologically. No other significant pathologies were found. The conservative treatment applied resulted in a gradual improvement in the patient's condition, relief from previously reported somatic symptoms, including persistent constipation, vomiting and headache, and a decrease in total calcium and creatinine (Fig. 1).

The patient was discharged home in a good general condition with further follow-up at the Nephrology Outpatient Clinic recommended.

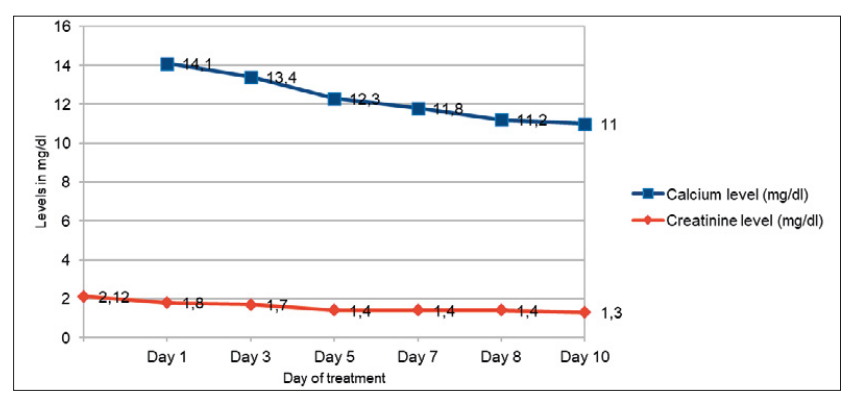

Figure 1. Changes in calcium and creatinine levels during treatment 


\section{DISCUSSION}

Hypercalcaemia is a fairly rare cause of acute kidney injury. The etiopathological mechanism is multi-directional and may be associated with dehydration in the course of polyuria, precipitation of calcium deposits in the renal tubules and the renal parenchyma associated with increased calcium load in urine. Nephrolithiasis, as well as stenosis of renal vessels and decrease in glomerular filtration [3]. In the described patient, the differential diagnostics of the causes of renal failure should take into account the inclusion of sartan, which in some clinical situations, such as bilateral renal artery stenosis, may cause acute renal injury, as well as excessive use of non-steroid anti-inflammatory drugs which, affecting the metabolism of prostaglandins, play a role in renal blood supply. Long-term use of NSAIDs may, in turn, cause the development of analgesic nephropathy. Acute tubulointerstitial nephritis, the use of non-steroidal anti-inflammatory drugs is one of the most common causes of, should also not be forgotten. However, these causes, as well as other causes of hypercalcaemia, including multiple myeloma, bone metastasis and hyperparathyroidism, were excluded in the course of the patient's observation and in the light of laboratory and imaging studies. The most likely cause seemed to be vitamin D intake.

The treatment of vitamin D deficiency is an extremely important issue in everyday medical work; however, it is important to consider possible side-effects of the drugs used, as well as specific recommendations for certain groups of patients. These include, among others, patients with granulomatous diseases, such as tuberculosis or sarcoidosis, in whom there is an autonomous and uncontrolled production of active metabolites of vitamin $\mathrm{D}$ in granulomatous tissue under the influence of INF- $\gamma$ (gamma interferon) and TNF- $\alpha$ (tumour necrosis factor $\alpha$ ) synthesised by stimulated lymphocytes and macrophages [4]. The target level of vitamin $\mathrm{D}$, and more precisely calcidiol $(25 \mathrm{OH}-\mathrm{D})$, the most frequently determined in clinical practice, in this group of patients should not exceed $25 \mathrm{ng} / \mathrm{ml}$. according to the Guidelines for Supplementation of Vitamin D for Central Europe [2]. While the normal values in the group of healthy people ranges from $30-50 \mathrm{ng} / \mathrm{ml}$ [2]. In the described patient, the level of calcidiol after admission to the hospital was $69.06 \mathrm{ng} / \mathrm{ml}$, which is still within the range of values considered non-toxic, but in the context of co-existing sarcoidosis, the patient developed symptomatic hypercalcaemia. Changes in the level of vitamin $25(\mathrm{OH}) \mathrm{D}$ before and after the start of supplementation are shown in Figure 2.

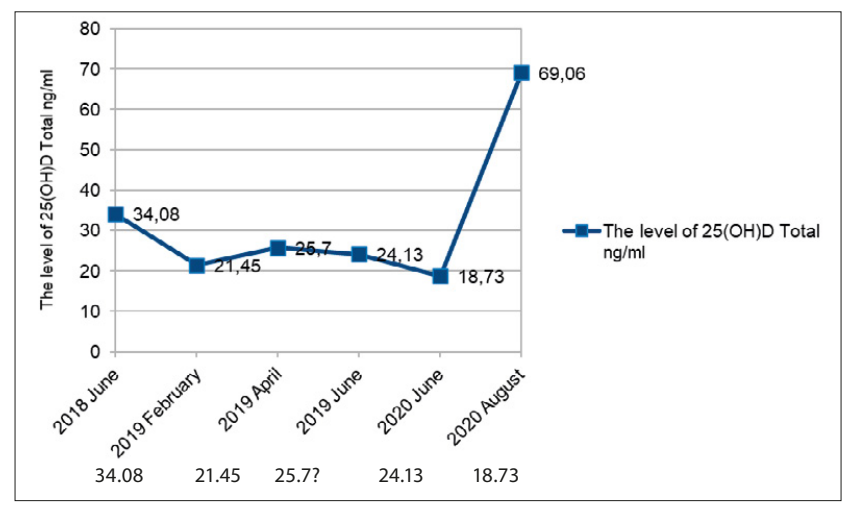

Figure 2. Level of $25(\mathrm{OH}) \mathrm{D}$

In conclusion, it should be remembered that the use of vitamin $\mathrm{D}$ in some clinical situations may lead to sideeffects, including acute kidney injury. For this reason, its supplementation should be recommended after each analysis of the patient's condition. Serum calcium levels should be monitored in patients receiving vitamin $\mathrm{D}$ supplementation.

\section{REFERENCES}

1. Jean G, Souberbielle JC, Chazot Ch. Vitamin D in Chronic Kidney Disease and Dialysis Patients. Nutrients. 2017 Apr; 9(4): 328. https:// doi.org/10.3390/nu9040328

2. Płudowski P, Kaczmarewicz E, Bayer M, et al. Wytyczne suplementacji witaminą D dla Europy Środkowej: Rekomendowane dawki witaminy D dla populacji zdrowej oraz dla grup ryzyka deficytu witaminy D. Endokrynol Pol. 2013; 64(4): 319-327.

3. Kempisty A, Kuś J. Hiperkalcemia i uszkodzenie nerek w przebiegu sarkoidozy. Pneumonol Alergol Pol. 2012; 80(6): 570-575.

4. Targowski T. Differences of metabolism of Vitamin D in sarcoidosis. Post N Med. 2016; XXIX(10): 750-752. 